\title{
CATALYTIC GASIFICATION OF COAL USING EUTECTIC SALT MIXTURES
}

Report for the period

October 1, 2000 to March 31, 2001

Dr. Yaw D. Yeboah (PI) and Dr. Yong Xu (Co-PI)

Department of Engineering Clark Atlanta University

Atlanta, Georgia 30314

Dr. Atul Sheth (Co-PI) and Mr. Chandramouli Sastry

The University of Tennessee Space Institute

411 B.H. Goethet Parkway

Tullahoma, TN 37388-8897

Dr. Pradeep Agrawal (Co-PI) and Ms. Mary Minton

School of Chemical Engineering

Georgia Institute of Technology

Atlanta, GA 30332

PREPARED FOR THE UNITED STATES DEPARTMENT OF ENERGY

UNDER CONTRACT NUMBER DE-FG26-97FT97263 


\begin{abstract}
Most of the tasks on the project have successfully been completed and reported. A 12 month no-cost extension has been requested to complete the remaining tasks. This report summarizes the accomplishments of the first six months of the no-cost extensions period.

The acetic acid extraction showed that acetic acid has more effect on the extraction of the ternary catalyst (LNK) ions than water. Based on the extraction results, the order of the recovery capability of $\mathrm{Na}_{2} \mathrm{CO}_{3}$ using acetic acid, sulfuric acid and water extractions is sulfuric acid $\geq$ acetic acid >water; the order for $\mathrm{K}_{2} \mathrm{CO}_{3}$ is sulfuric acid > water >acetic acid; and the order for $\mathrm{Li}_{2} \mathrm{CO}_{3}$ is acetic acid > sulfuric acid >water. A process flowsheet for the catalyst recovery process was proposed based on the results.

Scanning electron microscopy (SEM) studies showed most of the particles (coal) appear amorphous. Some coal particles are as large as 50-60 um, but most are smaller. One can also easily see a few crystalline particles (10-20 um) with sharp facets and corners. The electron micrographs of gasified char samples (reactor-aged) of the LNKcoal mixture showed that a dramatic change is obvious in the morphology and crystallinity of the sample and is consistent with the results obtained from the $\mathrm{x}$-ray diffraction studies. XRD studies of reactor-aged samples showed a substantial increase in the sample crystallinity (due to the gasification of amorphous carbon). The eutectic salt presumably mostly converted to sulfates.
\end{abstract}

The project is expected to successfully be completed in the next six months. 


\subsection{INTRODUCTION AND OBJECTIVES}

This progress report for the DOE grant DE-FG26-97FT97263 entitled, "Catalytic Gasification of Coal Using Eutectic Salt Mixtures" covers the period October 1, 2000 to March 31, 2001. The overall objectives of the project are to identify appropriate eutectic salt mixture catalysts for coal gasification; assess agglomeration tendency of catalyzed coal; evaluate various catalyst impregnation techniques to improve initial catalyst dispersion; evaluate effects of major process variables (such as temperature and system pressure) on coal gasification; evaluate the recovery, regeneration and recycle of the spent catalysts; and conduct thorough analysis and modeling of the gasification process to provide better understanding of the fundamental mechanisms and kinetics of the process.

To achieve the objectives, the project was subdivided into the following tasks.

Task 1 Selection of Eutectic Salt Mixtures: This task involves literature review; identification of appropriate eutectic salt mixtures; assessment of agglomeration tendency of the catalyzed coal; evaluation of catalyst application methods; and thermogravimeteric analysis (TGA) studies to evaluate gasification characteristics.

Task 2 Evaluation of gasification performance in a bench-scale, fixed-bed reactor: This task includes evaluation of catalyst dispersion; study of the effects of process variables on the performance of gasifiers; and evaluation of the recovery, regeneration and recycle of the catalysts.

Task 3 Data Analysis and Reporting: This encompasses data analysis and modeling; economic evaluation of the gasification process; and project management and reporting.

A summary of the progress and accomplishments on the project tasks is given in the next section. 


\subsection{SUMMARY OF PROJECT ACCOMPLISHMENTS}

\subsection{Task 1 Selection of Eutectic Salt Mixtures}

This task which involved literature review; identification of appropriate eutectic salt mixtures; assessment of the agglomeration tendency of catalyzed coal; evaluation of catalyst application methods; and TGA studies to evaluate gasification characteristics has been completed and reported in previous reports. A summary of the work and results of the task will be included in the final report.

\subsection{Task 2: Evaluation of gasification performance in a bench-scale, fixed-bed reactor}

The part of this task that involved the study of the effects of process variables on the performance of gasifiers has been completed and reported in previous progress reports.

The SEM and XRD characterization of the eutectic catalysts with and without coal/char have been studied and reported in previous progress reports to DOE. The detailed evaluation of catalyst dispersion continues to be carried out and will be completed during the no-cost extension period. It is envisaged that SEM studies together with energy dispersive analysis of x-rays (EDAX) would allow us to look at the morphology of the fresh and aged catalysts. In addition, such analysis would also lead to identification of any amorphous phases presently not identified by the XRD studies. Thus, when one integrates the XRD results with SEM/EDAX results, a more comprehensive and complete picture of the active catalytic moieties, their dispersion and the cause(s) of catalyst deactivation may be obtained.

Based on the TGA studies reported in previous progress reports, the $43.5 \%$ $\mathrm{Li}_{2} \mathrm{CO}_{3}-31.5 \% \quad \mathrm{Na}_{2} \mathrm{CO}_{3}-25 \% \quad \mathrm{~K}_{2} \mathrm{CO}_{3}(\mathrm{LNK})$ and $39 \% \quad \mathrm{Li}_{2} \mathrm{CO}_{3}-38.5 \% \quad \mathrm{Na}_{2} \mathrm{CO}_{3}-22.5 \%$ $\mathrm{Rb}_{2} \mathrm{CO}_{3}(\mathrm{LNR})$ ternary eutectics and the $29 \% \mathrm{Na}_{2} \mathrm{CO}_{3}-71 \% \mathrm{~K}_{2} \mathrm{CO}_{3}(\mathrm{NK})$ binary eutectic were selected for the performance evaluation of the fixed bed gasifier and the recovery studies of the spent catalysts in the bench scale fixed-bed reactor. 
The evaluation of the gasification performance in the bench-scale fixed-bed reactor has been completed and reported. The initial results of the recovery of the catalysts were presented in the previous progress report and concentrated on the effect of various factors such as water-to-char ratio, mixing time, temperature and acid extraction on the efficiency of binary catalyst (NK) recovery from the gasified char. During the first six months of the 12-month extension, similar experiments and analyses were conducted with the ternary LNK catalyst system and the results are discussed below.

\subsection{SUMMARY OF SIX MONTHS ACTIVITIES}

\section{Task 2: Catalyst Recovery and Regeneration Task}

In the previous report, extraction of NK catalyst with water and sulfuric acid and the effect of liquid-to-char ratio and temperature on the extraction efficiency were discussed. The study of the effects of water-to-char ratio and agitation time on the catalyst recovery showed that these two parameters do not significantly affect the extraction efficiency of the catalyst ions from the gasified char. Temperature has a strong effect on the extraction of the binary (NK) and ternary (LNK) catalysts. Sulfuric acid had more effect on the extraction of the binary catalyst (NK) ions than water. This report will

present the results of acetic acid extraction for the ternary catalyst (LNK) and the analyses of the data collected during all the extraction experiments for both ternary catalyst (LNK) and binary catalyst (NK).

\subsection{Materials}

Coal was prepared from ground Illinois \#6. Compositional data for the parent coal and for the char prepared from it are given in Table 1. The coal used in the lab was 60 mesh. 
Table 1 Compositional data for Illinois No.6 coal ( hvCb rank )

\begin{tabular}{|c|c|c|c|}
\hline \multicolumn{2}{|c|}{ Proximate analysis(wt. \%) } & \multicolumn{2}{c|}{ Ultimate analysis(wt. \%) } \\
\hline $\mathrm{H}_{2} \mathrm{O}$ & 13.20 & Ash & 11.62 \\
\hline Ash & 11.62 & $\mathrm{C}$ & 57.33 \\
\hline Volatiles & 35.44 & $\mathrm{H}$ & 3.98 \\
\hline Fixed C & 39.74 & $\mathrm{~N}$ & 0.99 \\
\hline & & $\mathrm{S}$ & 4.80 \\
\hline & & $\mathrm{O}$ & 8.07 \\
\hline
\end{tabular}

The salts investigated as catalysts and used for preparing the eutectic salts included Sigma Chemical $\mathrm{Co}$ analytical reagent grade $\mathrm{Rb}_{2} \mathrm{CO}_{3}, \mathrm{Li}_{2} \mathrm{CO}_{3}, \mathrm{Na}_{2} \mathrm{CO}_{3}$ and $\mathrm{K}_{2} \mathrm{CO}_{3}$.

\subsection{Sample preparation}

The ternary and binary eutectic catalysts were added to the raw coal by physical mixing and pyrolyzed at $750{ }^{\circ} \mathrm{C}$ for 3 hours. The pyrolyzed char was crushed and sieved to get a feed to the reactor whose particle size varied between 30 mesh and 100 mesh.

\subsection{Acetic Acid Extraction}

Based on stoichiometry and the composition of the gasified char, the minimum acid concentration required for complete reaction with the alkali salts present in the char, was calculated. After calculation, it was found that the minimum theoretical concentration of $30 \mathrm{ml}$ of sulfuric acid solution to completely react with $2 \mathrm{~g}$ of gasified char was $0.5 \mathrm{M}$. So, experiments were conducted with acid concentrations varying from $0.5 \mathrm{M}$ to $2.0 \mathrm{M}$. The extraction filtrates were analyzed in an ICP and the percentage recovery of the alkali metals $(\mathrm{Na}$ and $\mathrm{K})$ were determined. The results are tabulated below.

Table 2 Effect of acid concentration on extraction efficiency

\begin{tabular}{|c|c|c|c|}
\hline \multirow{2}{*}{$\begin{array}{c}\text { Concentration } \\
\text { Component }\end{array}$} & $0.5 \mathrm{M}$ & $1.0 \mathrm{M}$ & $2.0 \mathrm{M}$ \\
\cline { 2 - 4 } & \multicolumn{3}{|c|}{ Wt. Percentage Recovery } \\
\hline $\mathrm{Na}$ & 93.2 & 100 & 100 \\
\hline $\mathrm{K}$ & 59.5 & 74.5 & 88.4 \\
\hline
\end{tabular}


The graph of the tabulated values is shown in Figure 1 below. The values show that extraction is more efficient with acetic acid as solvent than with water. Even in the case of LNK catalyst, nearly $100 \%$ percent extraction was obtained in acetic acid extraction.

Figure 1 Effect of acid concentration on extration efficiency

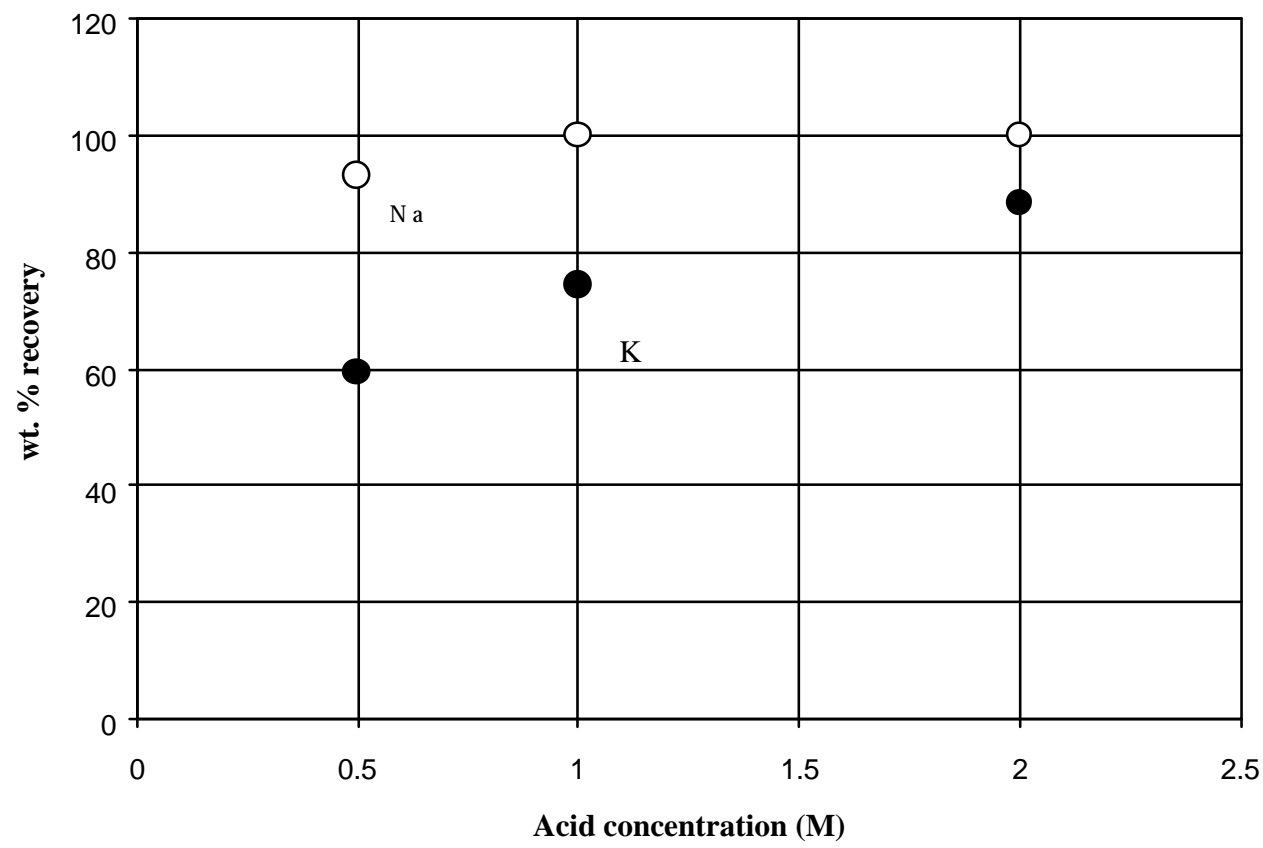

\section{Catalyst Recovery Data Interpretation for LNK gasified char}

\subsection{Water Extraction Analysis}

$2 \mathrm{~g}$ of LNK gasified char was taken to analyze. Water extract of this $2 \mathrm{~g}$ char was collected at $93.5^{\circ} \mathrm{C}$ and the filtrate was analyzed by the project team and by an outside lab. The composite results are shown in Table 3.

Table 3 Composition from water extractions

\begin{tabular}{|c|c|c|c|}
\hline Component & Gasified Char & Water Extract & Water Insoluble \\
\hline $\mathrm{Li}$ & $63.4 \mathrm{mg}=9.13 \mathrm{mmol}$ & $4.76 \mathrm{mg}=0.69 \mathrm{mmol}$ & $8.44 \mathrm{mmol}$ \\
\hline $\mathrm{Na}$ & $159 \mathrm{mg}=6.91 \mathrm{mmol}$ & $123 \mathrm{mg}=5.35 \mathrm{mmol}$ & $1.56 \mathrm{mmol}$ \\
\hline $\mathrm{K}$ & $199 \mathrm{mg}=5.10 \mathrm{mmol}$ & $147 \mathrm{mg}=3.77 \mathrm{mmol}$ & $1.33 \mathrm{mmol}$ \\
\hline Sulfide as 'S' & $0 \mathrm{mg}=0.00 \mathrm{mmol}$ & $0 \mathrm{mg}=0.00 \mathrm{mmol}$ & $2.28 \mathrm{mmol}$ \\
\hline Sulfate as 'S' & $142 \mathrm{mg}=4.44 \mathrm{mmol}$ & $141 \mathrm{mg}=4.40 \mathrm{mmol}$ & $0.04 \mathrm{mmol}$ \\
\hline
\end{tabular}


From the ' water extract' column in the table above, the water extract contains $\mathrm{Li}_{2} \mathrm{SO}_{4}, \mathrm{Na}_{2} \mathrm{SO}_{4}$ and $\mathrm{K}_{2} \mathrm{SO}_{4}$ without sulfides. It was found that the extract contained some carbonates, bicarbonates and hydroxides at this $\mathrm{pH}$ measurement condition. Based on this information, the water extract was assumed to have the following compounds and composition:

$\begin{array}{lll}\mathrm{X}_{1} \mathrm{mmol} \mathrm{Li}_{2} \mathrm{CO}_{3} & \mathrm{X}_{5} \mathrm{mmol} \mathrm{Na} \mathrm{CO}_{3} & \mathrm{X}_{9} \mathrm{mmol} \mathrm{K}_{2} \mathrm{CO}_{3} \\ \mathrm{X}_{2} \mathrm{mmol} \mathrm{LiHCO} & \mathrm{X}_{6} \mathrm{mmol} \mathrm{NaHCO} & \mathrm{X}_{10} \mathrm{mmol} \mathrm{KHCO}_{3} \\ \mathrm{X}_{3} \mathrm{mmol} \mathrm{LiOH} & \mathrm{X}_{7} \mathrm{mmol} \mathrm{NaOH} & \mathrm{X}_{11} \mathrm{mmol} \mathrm{KOH} \\ \mathrm{X}_{4} \mathrm{mmol} \mathrm{Li}_{2} \mathrm{SO}_{4} & \mathrm{X}_{8} \mathrm{mmol} \mathrm{Na}_{2} \mathrm{SO}_{4} & \mathrm{X}_{12} \mathrm{mmol} \mathrm{K}_{2} \mathrm{SO}_{4}\end{array}$

Molar balances on $\mathrm{Li}, \mathrm{Na}, \mathrm{K}$ and Sulfate ' $\mathrm{S}$ ' were made respectively as.

$$
\begin{aligned}
& 2 X_{1}+X_{2}+X_{3}+2 X_{4}=0.69 \\
& 2 X_{5}+X_{6}+X_{7}+2 X_{8}=5.35 \\
& 2 X_{9}+X_{10}+X_{11}+2 X_{12}=3.77 \\
& X_{4}+X_{8}+X_{12}=4.40
\end{aligned}
$$

In this $\mathrm{pH}$ range between 11 and 12 , it was found that

Molar ratio $\left[\mathrm{CO}_{3}^{--}\right] /\left[\mathrm{HCO}_{3}^{-}\right]=9$ and

Molar ratio $\left[\mathrm{CO}_{3}^{--}, \mathrm{HCO}_{3}^{-}\right] /\left[\mathrm{OH}^{-}\right]=15$

Hence,

$$
\begin{aligned}
& \left(\mathrm{X}_{1}+\mathrm{X}_{5}+\mathrm{X}_{9}\right) /\left(\mathrm{X}_{2}+\mathrm{X}_{6}+\mathrm{X}_{10}\right)=9 \text { and } \\
& \left(\mathrm{X}_{1}+\mathrm{X}_{2}+\mathrm{X}_{5}+\mathrm{X}_{6}+\mathrm{X}_{9}+\mathrm{X}_{10}\right) /\left(\mathrm{X}_{3}+\mathrm{X}_{7}+\mathrm{X}_{11}\right)=15
\end{aligned}
$$

Therefore,

$$
\begin{aligned}
& X_{1}-9 X_{2}+X_{5}-9 X_{6}+X_{9}-9 X_{10}=0 \\
& X_{1}+X_{2}-15 X_{3}+X_{5}+X_{6}-15 X_{7}+X_{9}+X_{10}-15 X_{11}=0
\end{aligned}
$$

It was assumed that the fraction of $\mathrm{Li}$ ions present as $\mathrm{CO}_{3}{ }^{--}$, the fraction of $\mathrm{Na}$ ions present as $\mathrm{CO}_{3}{ }^{-}$and the fraction of $\mathrm{K}$ ions present as $\mathrm{CO}_{3}{ }^{-}$were all the same. A similar assumption was made for all other anionic species present in the extract.

$$
\begin{aligned}
& 2 \mathrm{X}_{1} /\left(2 \mathrm{X}_{1}+\mathrm{X}_{2}+\mathrm{X}_{3}+2 \mathrm{X}_{4}\right)=2 \mathrm{X}_{5} /\left(2 \mathrm{X}_{5}+\mathrm{X}_{6}+\mathrm{X}_{7}+2 \mathrm{X}_{8}\right)=2 \mathrm{X}_{9} /\left(2 \mathrm{X}_{9}+\mathrm{X}_{10}+\mathrm{X}_{11}+2 \mathrm{X}_{12}\right) \\
& \mathrm{X}_{2} /\left(2 \mathrm{X}_{1}+\mathrm{X}_{2}+\mathrm{X}_{3}+2 \mathrm{X}_{4}\right)=\mathrm{X}_{6} /\left(2 \mathrm{X}_{5}+\mathrm{X}_{6}+\mathrm{X}_{7}+2 \mathrm{X}_{8}\right)=\mathrm{X}_{10} /\left(2 \mathrm{X}_{9}+\mathrm{X}_{10}+\mathrm{X}_{11}+2 \mathrm{X}_{12}\right) \\
& \mathrm{X}_{3} /\left(2 \mathrm{X}_{1}+\mathrm{X}_{2}+\mathrm{X}_{3}+2 \mathrm{X}_{4}\right)=\mathrm{X}_{7} /\left(2 \mathrm{X}_{5}+\mathrm{X}_{6}+\mathrm{X}_{7}+2 \mathrm{X}_{8}\right)=\mathrm{X}_{11} /\left(2 \mathrm{X}_{9}+\mathrm{X}_{10}+\mathrm{X}_{11}+2 \mathrm{X}_{12}\right) \\
& 2 \mathrm{X}_{4} /\left(2 \mathrm{X}_{1}+\mathrm{X}_{2}+\mathrm{X}_{3}+2 \mathrm{X}_{4}\right)=2 \mathrm{X}_{8} /\left(2 \mathrm{X}_{5}+\mathrm{X}_{6}+\mathrm{X}_{7}+2 \mathrm{X}_{8}\right)=2 \mathrm{X}_{12} /\left(2 \mathrm{X}_{9}+\mathrm{X}_{10}+\mathrm{X}_{11}+2 \mathrm{X}_{12}\right)
\end{aligned}
$$

or 


$$
\begin{aligned}
& X_{2} / X_{1}=X_{6} / X_{5}=X_{10} / X_{9} \\
& X_{3} / X_{2}=X_{7} / X_{6}=X_{11} / X_{10} \\
& X_{4} / X_{3}=X_{8} / X_{7}=X_{12} / X_{11}
\end{aligned}
$$

Therefore,

$$
\begin{aligned}
& X_{1} X_{6}-X_{2} X_{5}=0 \\
& X_{5} X_{10}-X_{6} X_{9}=0 \\
& X_{2} X_{7}-X_{3} X_{6}=0 \\
& X_{6} X_{11}-X_{7} X_{10}=0 \\
& X_{3} X_{8}-X_{4} X_{7}=0 \\
& X_{7} X_{12}-X_{8} X_{11}=0
\end{aligned}
$$

The above system of 12 equations was solved using the Microsoft Excel Solver to obtain the following solution

$$
\begin{array}{lll}
X_{1}=0.033 & X_{5}=0.252 & X_{9}=0.178 \\
X_{2}=0.004 & X_{6}=0.028 & X_{10}=0.020 \\
X_{3}=0.002 & X_{7}=0.019 & X_{11}=0.013 \\
X_{4}=0.309 & X_{8}=2.400 & X_{12}=1.691
\end{array}
$$

Hence, the approximate composition of the water extract was estimated to be:

$\begin{array}{lll}0.033 \mathrm{mmol} \mathrm{Li}_{2} \mathrm{CO}_{3} & 0.252 \mathrm{mmol} \mathrm{Na}_{2} \mathrm{CO}_{3} & 0.178 \mathrm{mmol} \mathrm{K}_{2} \mathrm{CO}_{3} \\ 0.004 \mathrm{mmol} \mathrm{LiHCO} & 0.028 \mathrm{mmol} \mathrm{NaHCO} & 0.020 \mathrm{mmol} \mathrm{KHCO}_{3} \\ 0.002 \mathrm{mmol} \mathrm{LiOH} & 0.019 \mathrm{mmol} \mathrm{NaOH} & 0.013 \mathrm{mmol} \mathrm{KOH} \\ 0.309 \mathrm{mmol} \mathrm{Li}_{2} \mathrm{SO}_{4} & 2.400 \mathrm{mmol} \mathrm{Na}_{2} \mathrm{SO}_{4} & 1.691 \mathrm{mmol} \mathrm{K}_{2} \mathrm{SO}_{4}\end{array}$

\subsection{Acetic Acid Extraction Analysis}

When acetic acid was used as the extraction solvent instead of water, all the compounds that were extracted with water were also assumed to be extracted with the acid. The additional recovery was assumed to come from the compounds that were insoluble in water. All of the water insoluble compounds were assumed to be in the form of aluminosilicates such as: $\left(\mathrm{Na}_{2} \mathrm{O}\right)_{\mathrm{x}}\left(\mathrm{Al}_{2} \mathrm{O}_{3}\right)_{\mathrm{y}}\left(\mathrm{SiO}_{2}\right)_{\mathrm{z}},\left(\mathrm{K}_{2} \mathrm{O}\right)_{\mathrm{x}}\left(\mathrm{Al}_{2} \mathrm{O}_{3}\right)_{\mathrm{y}}\left(\mathrm{SiO}_{2}\right)_{\mathrm{z}},\left(\mathrm{Li}_{2} \mathrm{O}\right)_{\mathrm{x}}$ $\left(\mathrm{Al}_{2} \mathrm{O}_{3}\right)_{\mathrm{y}}\left(\mathrm{SiO}_{2}\right)_{\mathrm{z}}$ and other non-alkali metal sulfides like $\mathrm{FeS}_{2}$ etc.

When the aluminosilicates reacted with acetic acid, $\mathrm{Li}, \mathrm{Na}$ and $\mathrm{K}$ were extracted in the form of acid-soluble acetates. The extent of $\mathrm{Li}, \mathrm{Na}$ and $\mathrm{K}$ recoveries depended on the 
acid concentration. The reaction between the aluminosilicates and acetic acid could be represented as shown below:

$\left(\mathrm{Na}_{2} \mathrm{O}\right)_{\mathrm{x}}\left(\mathrm{Al}_{2} \mathrm{O}_{3}\right)_{\mathrm{y}}\left(\mathrm{SiO}_{2}\right)_{\mathrm{z}}+2 \mathrm{x} \mathrm{CH}_{3} \mathrm{COOH} \rightarrow 2 \mathrm{x} \mathrm{CH}_{3} \mathrm{COONa}+\mathrm{y} \mathrm{Al}_{2} \mathrm{O}_{3}+\mathrm{z} \mathrm{SiO}_{2}+\mathrm{x} \mathrm{H}_{2} \mathrm{O}$

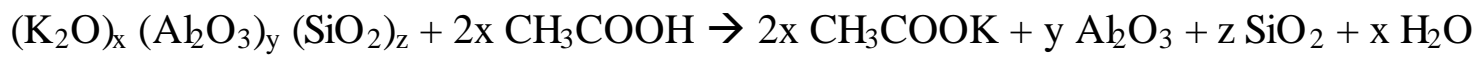

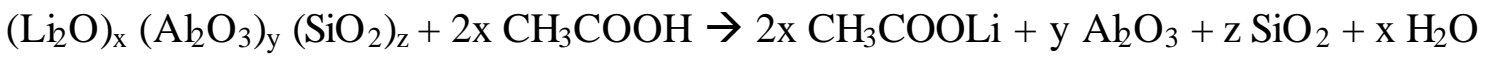

All the water-soluble $\mathrm{Li}, \mathrm{Na}$ and $\mathrm{K}$ compounds in the water extracts were in the form of carbonates, bicarbonates, hydroxides and sulfates. When acetic acid was used as the extraction solvent, except for the sulfates, all other $\mathrm{Li}, \mathrm{Na}$ and $\mathrm{K}$ compounds were expected to react with the acid forming alkali acetates. So, the only acid-soluble compounds in the acid extracts were assumed to be acetates and sulfates of $\mathrm{Li}, \mathrm{Na}$ and $\mathrm{K}$. Therefore, knowing the composition of water extracts (from the water extraction analysis) and the recoveries of $\mathrm{Li}, \mathrm{Na}$ and $\mathrm{K}$ in the acid extracts, the composition of the acetic acid extract was estimated.

The optimum recoveries of $\mathrm{Li}, \mathrm{Na}$ and $\mathrm{K}$ from acetic acid extracts were found to be: $\mathrm{Li}-93.9$ wt. $\%, \mathrm{Na}-98.7$ wt. $\%$ and $\mathrm{K}-64.8$ wt. $\%$. From these observations, $\mathrm{Li}, \mathrm{Na}$ and $\mathrm{K}$ balances were made as shown in Table 4:

Table 4 Composition from acetic acid extraction

\begin{tabular}{|c|c|c|c|}
\hline Component & Gasified Char & Acetic Acid Extract & Acid Insoluble \\
\hline $\mathrm{Li}$ & $9.13 \mathrm{mmol}$ & $8.57 \mathrm{mmol}$ & $0.56 \mathrm{mmol}$ \\
\hline $\mathrm{Na}$ & $6.91 \mathrm{mmol}$ & $6.82 \mathrm{mmol}$ & $0.09 \mathrm{mmol}$ \\
\hline $\mathrm{K}$ & $5.10 \mathrm{mmol}$ & $3.30 \mathrm{mmol}$ & $1.80 \mathrm{mmol}$ \\
\hline
\end{tabular}

Composition of the acetic acid extract was assumed to be:

\begin{tabular}{|c|c|c|}
\hline $\mathrm{X}_{1} \mathrm{mmol} \mathrm{CH}_{3} \mathrm{COOLi}$ & $\mathrm{X}_{3} \mathrm{mmol} \mathrm{CH}_{3} \mathrm{COONa}$ & $\mathrm{X}_{5} \mathrm{mmol} \mathrm{CH}_{3} \mathrm{COOK}$ \\
\hline $\mathrm{X}_{2} \mathrm{mmol} \mathrm{Li}_{2} \mathrm{SO}_{4}$ & $\mathrm{X}_{4} \mathrm{mmol} \mathrm{Na}_{2} \mathrm{SO}_{4}$ & $\mathrm{X}_{6} \mathrm{mmol} \mathrm{K}_{2} \mathrm{SO}_{4}$ \\
\hline
\end{tabular}

Molar balances on $\mathrm{Li}, \mathrm{Na}$ and $\mathrm{K}$ gave

$$
\begin{aligned}
& X_{1}+2 X_{2}=8.57 \\
& X_{3}+2 X_{4}=6.82 \\
& X_{5}+2 X_{6}=3.30
\end{aligned}
$$


The acetic acid extract was collected at room temperature. A water extract collected at room temperature was analyzed ( in a similar manner described earlier ) to give the following relevant results:
$0.173 \mathrm{mmol} \mathrm{Li}_{2} \mathrm{SO}_{4}$
$1.685 \mathrm{mmol} \mathrm{Na}_{2} \mathrm{SO}_{4}$
$1.142 \mathrm{mmol} \mathrm{K}_{2} \mathrm{SO}_{4}$

Since all the sulfates present in the water extract are also present in the acetic acid extract,

$$
\mathrm{X}_{1}=8.224 ; \mathrm{X}_{2}=0.173 ; \mathrm{X}_{3}=3.450 ; \mathrm{X}_{4}=1.685 ; \mathrm{X}_{5}=1.016 \mathrm{X}_{6}=1.142
$$

Therefore, the composition of acetic acid extract was estimated to be:
$8.224 \mathrm{mmol} \mathrm{CH}{ }_{3} \mathrm{COOLi}$
$3.450 \mathrm{mmol} \mathrm{CH}_{3} \mathrm{COONa}$
$1.016 \mathrm{mmol} \mathrm{CH}_{3} \mathrm{COOK}$
$0.173 \mathrm{mmol} \mathrm{Li}_{2} \mathrm{SO}_{4}$
$1.685 \mathrm{mmol} \mathrm{Na}_{2} \mathrm{SO}_{4}$
$1.142 \mathrm{mmol} \mathrm{K}_{2} \mathrm{SO}_{4}$

\subsection{Sulfuric Acid Extraction Analysis}

Sulfuric acid extracts were analyzed in the same manner as acetic acid extracts. The acid extracts in this case contained sulfates of $\mathrm{Li}, \mathrm{Na}$ and $\mathrm{K}$. The optimum percentage recoveries of $\mathrm{Li}, \mathrm{Na}$ and $\mathrm{K}$ were found to be $\mathrm{Li}-78.7 \%$ (by wt.); $\mathrm{Na}-99 \%$ (by wt.) and $\mathrm{K}-98.6 \%$ (by wt.). From these observations, $\mathrm{Li}, \mathrm{Na}$ and $\mathrm{K}$ balances were made as shown ( Table 5):

Table 5 Composition from sulfuric acid extraction

\begin{tabular}{|c|c|c|c|}
\hline Component & Gasified Char & Sulfuric Acid Extract & Acid Insoluble \\
\hline $\mathrm{Li}$ & $9.13 \mathrm{mmol}$ & $7.19 \mathrm{mmol}$ & $1.94 \mathrm{mmol}$ \\
\hline $\mathrm{Na}$ & $6.91 \mathrm{mmol}$ & $6.84 \mathrm{mmol}$ & $0.07 \mathrm{mmol}$ \\
\hline $\mathrm{K}$ & $5.10 \mathrm{mmol}$ & $5.03 \mathrm{mmol}$ & $0.07 \mathrm{mmol}$ \\
\hline
\end{tabular}

Sulfuric acid extract was assumed to have the composition:

$$
\mathrm{X}_{1} \mathrm{mmol} \mathrm{Li}_{2} \mathrm{SO}_{4} \quad \mathrm{X}_{2} \mathrm{mmol} \mathrm{Na}_{2} \mathrm{SO}_{4} \quad \mathrm{X}_{3} \mathrm{mmol} \mathrm{K}_{2} \mathrm{SO}_{4}
$$

Molar balances on $\mathrm{Li}, \mathrm{Na}$ and $\mathrm{K}$ gave

$$
\mathrm{X}_{1}=3.60 ; \quad \mathrm{X}_{2}=3.42 ; \quad \mathrm{X}_{3}=2.51
$$

Therefore, the composition of sulfuric acid extract was found to be :
$3.60 \mathrm{mmol} \mathrm{Li}_{2} \mathrm{SO}_{4}$
$3.42 \mathrm{mmol} \mathrm{Na}_{2} \mathrm{SO}_{4}$
$2.51 \mathrm{mmol} \mathrm{K}_{2} \mathrm{SO}_{4}$ 
A summary of all three extract analyses is shown in Table 6:

Table 6 Composition from different extraction agents

\begin{tabular}{|l|l|l|l|}
\hline $\begin{array}{c}\text { Gasified } \\
\text { Char } \\
(\mathrm{mmol})\end{array}$ & \multicolumn{1}{|c|}{$\begin{array}{c}\text { Water } \\
\text { Extraction } \\
\mathrm{mmol})\end{array}$} & $\begin{array}{c}\text { Acetic Acid } \\
\text { Extraction } \\
(\mathrm{mmol})\end{array}$ & $\begin{array}{c}\text { Sulfuric Acid } \\
\text { Extraction } \\
(\mathrm{mmol})\end{array}$ \\
\hline $\mathrm{Li}-9.13$ & $\mathrm{Na}_{2} \mathrm{SO}_{4}-2.400$ & $\mathrm{CH}_{3} \mathrm{COOLi}-8.224$ & $\mathrm{Li}_{2} \mathrm{SO}_{4}-3.6$ \\
\hline $\mathrm{Ka}-6.91$ & $\mathrm{~K}_{2} \mathrm{SO}_{4}-1.691$ & $\mathrm{Na}_{2} \mathrm{SO}_{4}-1.685$ & $\mathrm{Na}_{2} \mathrm{SO}_{4}-3.42$ \\
\hline & $\mathrm{Li}_{2} \mathrm{SO}_{4}-0.309$ & $\mathrm{CH}_{3} \mathrm{COONa}-3.45$ & $\mathrm{~K}_{2} \mathrm{SO}_{4}-2.51$ \\
\hline & $\mathrm{Na}_{2} \mathrm{CO}_{3}-0.252$ & $\mathrm{~K}_{2} \mathrm{SO}_{4}-1.142$ & \\
\hline & $\mathrm{K}_{2} \mathrm{CO}_{3}-0.178$ & $\mathrm{CH}_{3} \mathrm{COOK}-1.016$ & \\
\hline & $\mathrm{Li}_{2} \mathrm{CO}_{3}-0.033$ & $\mathrm{Li}_{2} \mathrm{SO}_{4}-0.173$ & \\
\hline & $\mathrm{NaHCO}_{3}-0.028$ & & \\
\hline & $\mathrm{KHCO}-0.020$ & & \\
\hline & $\mathrm{NaOH}-0.019$ & & \\
\hline & $\mathrm{KOH}-0.013$ & & \\
\hline & $\mathrm{LiHCO}-0.004$ & & \\
\hline & $\mathrm{LiOH}-0.002$ & & \\
\hline
\end{tabular}

\subsection{Calculating the quantity of $\mathrm{Li}_{2} \mathrm{CO}_{3}, \mathrm{Na}_{2} \mathrm{CO}_{3}$ and $\mathrm{K}_{2} \mathrm{CO}_{3}$ in the fresh catalyst}

The basis of all the calculations had been $2 \mathrm{~g}$ of gasified char. The quantity of feed required to get $2 \mathrm{~g}$ of gasified char was calculated by the use of a few observations that were found to be constant in all gasification experiments:

$30 \mathrm{~g}$ of feed ( $27 \mathrm{~g}$ raw coal $+3 \mathrm{~g}$ catalyst) on pyrolysis gave $17.0 \mathrm{~g}$ of pyrolyzed coal.

$10 \mathrm{~g}$ of this pyrolyzed coal on gasification gave $3.25 \mathrm{~g}$ of gasified char.

So, to get $2 \mathrm{~g}$ of gasified char, $10.86 \mathrm{~g}$ of feed was needed. The feed contained $10 \mathrm{wt}$. $\%$ catalyst. So, the feed had $1.086 \mathrm{~g}$ of catalyst. Hence, the quantity of $\mathrm{Li}_{2} \mathrm{CO}_{3}, \mathrm{Na}_{2} \mathrm{CO}_{3}$ and $\mathrm{K}_{2} \mathrm{CO}_{3}$ in the feed was found to be

$\mathrm{Li}_{2} \mathrm{CO}_{3}: 4.72 \mathrm{mmol} ; \quad \mathrm{Na}_{2} \mathrm{CO}_{3}: 3.43 \mathrm{mmol} ; \quad \mathrm{K}_{2} \mathrm{CO}_{3}: 2.71 \mathrm{mmol}$

\subsection{Calculating the quantity of make-up catalyst for each of the three extraction schemes}

In calculating the make-up catalyst for the process, it was assumed that all the $\mathrm{Li}, \mathrm{Na}$ and $\mathrm{K}$ present in the extract could be recovered as dry powder (in the form of carbonates). 


\section{- Water Extraction}

Recoverable $\mathrm{Li}_{2} \mathrm{CO}_{3}: 0.309 \mathrm{mmol}\left(\right.$ from $\left.\mathrm{Li}_{2} \mathrm{SO}_{4}\right)+0.033 \mathrm{mmol}\left(\right.$ from $\left.\mathrm{Li}_{2} \mathrm{CO}_{3}\right)+$ 0.004/2 mmol (from $\left.\mathrm{LiHCO}_{3}\right)+0.002 / 2 \mathrm{mmol}($ from $\mathrm{LiOH})$ $=0.345 \mathrm{mmol} \quad \ldots .$. (values from table on the previous page)

Make-up $\mathrm{Li}_{2} \mathrm{CO}_{3}: 4.72-0.345=4.375 \mathrm{mmol}$

Recoverable $\mathrm{Na}_{2} \mathrm{CO}_{3}: 2.4+0.252+0.028 / 2+0.019 / 2=2.6755 \mathrm{mmol}$

Make-up $\mathrm{Na}_{2} \mathrm{CO}_{3}: 3.43-2.6755=0.7545 \mathrm{mmol}$

Recoverable $\mathrm{K}_{2} \mathrm{CO}_{3}: 1.691+0.178+0.020 / 2+0.013 / 2=1.8855 \mathrm{mmol}$

Make-up $\mathrm{K}_{2} \mathrm{CO}_{3}: 2.71-1.8855=0.8245 \mathrm{mmol}$

\section{- Acetic Acid Extraction}

Recoverable $\mathrm{Li}_{2} \mathrm{CO}_{3}: 8.224 / 2+0.173=4.285 \mathrm{mmol}$

Make-up $\mathrm{Li}_{2} \mathrm{CO}_{3}: 4.72-4.285=0.435 \mathrm{mmol}$

Recoverable $\mathrm{Na}_{2} \mathrm{CO}_{3}: 3.45 / 2+1.685=3.41 \mathrm{mmol}$

Make-up $\mathrm{Na}_{2} \mathrm{CO}_{3}: 3.43-3.41=0.02 \mathrm{mmol}$

Recoverable $\mathrm{K}_{2} \mathrm{CO}_{3}: 1.016 / 2+1.142=1.65 \mathrm{mmol}$

Make-up $\mathrm{K}_{2} \mathrm{CO}_{3}: 2.71-1.65=1.06 \mathrm{mmol}$

\section{- Sulfuric Acid Extraction}

Recoverable $\mathrm{Li}_{2} \mathrm{CO}_{3}$ : $3.6 \mathrm{mmol}$

Make-up $\mathrm{Li}_{2} \mathrm{CO}_{3}: 4.72-3.6=1.12 \mathrm{mmol}$

Recoverable $\mathrm{Na}_{2} \mathrm{CO}_{3}: 3.42 \mathrm{mmol}$

Make-up $\mathrm{Na}_{2} \mathrm{CO}_{3}: 3.43-3.42=0.01 \mathrm{mmol}$

Recoverable $\mathrm{K}_{2} \mathrm{CO}_{3}: 2.51 \mathrm{mmol}$

Make-up $\mathrm{K}_{2} \mathrm{CO}_{3}: 2.71-2.51=0.20 \mathrm{mmol}$ 
A summary of the above calculations is shown in the table below (Table 7):

Table 7 Composition of make-up catalysts from different extraction agents

\begin{tabular}{|c|c|c|c|}
\hline & \multicolumn{3}{|c|}{ Make-up Catalyst for } \\
\hline & $\begin{array}{c}\text { Water Extraction } \\
(\mathrm{mmol})\end{array}$ & $\begin{array}{c}\text { Acetic Acid Extraction } \\
(\mathrm{mmol})\end{array}$ & $\begin{array}{c}\text { Sulfuric Acid Extraction } \\
(\mathrm{mmol})\end{array}$ \\
\hline $\mathrm{Li}_{2} \mathrm{CO}_{3}$ & 4.375 & 0.435 & 1.12 \\
\hline $\mathrm{Na}_{2} \mathrm{CO}_{3}$ & 0.7545 & 0.02 & 0.01 \\
\hline $\mathrm{K}_{2} \mathrm{CO}_{3}$ & 0.8245 & 1.06 & 0.20 \\
\hline
\end{tabular}

\section{Data Interpretation for NK gasified char}

The procedure followed in interpreting the experimental data for the LNK gasified char was adopted in NK gasified char also. The summary of the data analysis is shown below (Table 8). Composition of all three extracts were from $2 \mathrm{~g}$ of gasified char.

Table 8 Composition of NK gasified char from different extraction agents

\begin{tabular}{|c|l|l|l|}
\hline $\begin{array}{c}\text { Gasified Char } \\
(\mathrm{mmol})\end{array}$ & $\begin{array}{c}\text { Water Extraction } \\
(\mathrm{mmol})\end{array}$ & $\begin{array}{c}\text { Acetic Acid } \\
\text { Extraction } \\
(\mathrm{mmol})\end{array}$ & $\begin{array}{c}\text { Sulfuric Acid } \\
\text { Extraction } \\
(\mathrm{mmol})\end{array}$ \\
\hline $\mathrm{K}-10.36$ & $\mathrm{~K}_{2} \mathrm{SO}_{4}-1.748$ & $\mathrm{CH}_{3} \mathrm{COOK}-6.36$ & $\mathrm{~K}_{2} \mathrm{SO}_{4}-4.97$ \\
\hline $\mathrm{Na}-4.65$ & $\mathrm{~K}_{2} \mathrm{CO}_{3}-0.935$ & $\mathrm{CH}_{3} \mathrm{COONa}-3.622$ & $\mathrm{Na}_{2} \mathrm{SO}_{4}-2.23$ \\
\hline & $\mathrm{Na}_{2} \mathrm{SO}_{4}-0.852$ & $\mathrm{~K}_{2} \mathrm{SO}_{4}-1.4$ & \\
\hline & $\mathrm{Na}_{2} \mathrm{CO}_{3}-0.456$ & $\mathrm{Na}_{2} \mathrm{SO}_{4}-0.514$ & \\
\hline & $\mathrm{KHCO}_{3}-0.104$ & & \\
\hline & $\mathrm{KOH}-0.069$ & & \\
\hline & $\mathrm{NaHCO}-0.051$ & & \\
\hline & $\mathrm{NaOH}-0.034$ & & \\
\hline
\end{tabular}

Quantity of make-up catalyst needed for the three extraction methods:

Table 9 Composition of make-up catalysts from different extraction agents

\begin{tabular}{|c|c|c|c|}
\hline & \multicolumn{3}{|c|}{ Make-up Catalyst for } \\
\hline & $\begin{array}{c}\text { Water Extraction } \\
(\mathrm{mmol})\end{array}$ & $\begin{array}{c}\text { Acetic Acid Extraction } \\
(\mathrm{mmol})\end{array}$ & $\begin{array}{c}\text { Sulfuric Acid Extraction } \\
(\mathrm{mmol})\end{array}$ \\
\hline $\mathrm{Na}_{2} \mathrm{CO}_{3}$ & 1.0135 & 0.039 & 0.134 \\
\hline $\mathrm{K}_{2} \mathrm{CO}_{3}$ & 3.015 & 1.205 & 0.815 \\
\hline
\end{tabular}




\section{Recovering the Catalyst from the Extract}

The fresh catalyst ingredients were in the form of $\mathrm{Li}_{2} \mathrm{CO}_{3}, \mathrm{Na}_{2} \mathrm{CO}_{3}$ and $\mathrm{K}_{2} \mathrm{CO}_{3}$. So, the catalyst recovered from the catalyst recovery process also needed to be in the same form.

To achieve this, extract from the extractor would be passed through an anion ionexchanger. Any sulfates present in the extract would be converted to bicarbonates. This solution, which may have contained carbonates, bicarbonates, hydroxides and acetates when concentrated (in an evaporator), would only have carbonates. This solution could be crystallized (in a crystallizer) to get solid $\mathrm{Li}_{2} \mathrm{CO}_{3}, \mathrm{Na}_{2} \mathrm{CO}_{3}$ and $\mathrm{K}_{2} \mathrm{CO}_{3}$.

Reactions in the anion ion-exchanger (for just one species) and the evaporator are given below:

\section{- Ion-Exchanger}

$$
\begin{aligned}
& \mathrm{R} . \mathrm{OH}\left(\text { resin) }+\mathrm{CO}_{2} \rightarrow \mathrm{R} \cdot \mathrm{HCO}_{3}\right. \\
& 2 \mathrm{R} . \mathrm{HCO}_{3}+\mathrm{K}_{2} \mathrm{SO}_{4} \rightarrow \mathrm{R}_{2} \cdot \mathrm{SO}_{4}+2 \mathrm{KHCO}_{3} \\
& \mathrm{R}_{2} . \mathrm{SO}_{4}+2 \mathrm{NH}_{4} \mathrm{OH} \rightarrow 2 \mathrm{R} \cdot \mathrm{OH}+\left(\mathrm{NH}_{4}\right)_{2} \mathrm{SO}_{4} \quad . . \text { (Resin regeneration step) }
\end{aligned}
$$

\section{- Evaporator}

$$
\begin{aligned}
& 2 \mathrm{KHCO}_{3} \stackrel{\Delta}{\longrightarrow} \mathrm{K}_{2} \mathrm{CO}_{3}+\mathrm{H}_{2} \mathrm{O}+\mathrm{CO}_{2} \\
& 2 \mathrm{CH}_{3} \mathrm{COOK}+4 \mathrm{O}_{2} \stackrel{\Delta}{\longrightarrow} \mathrm{K}_{2} \mathrm{CO}_{3}+3 \mathrm{H}_{2} \mathrm{O}+3 \mathrm{CO}_{2} \\
& 2 \mathrm{KOH}+\mathrm{CO}_{2} \stackrel{\Delta}{\longrightarrow} \mathrm{K}_{2} \mathrm{CO}_{3}+\mathrm{H}_{2} \mathrm{O}
\end{aligned}
$$

Based on the discussion presented so far, a process flow sheet was developed incorporating all the important steps in the gasification and catalyst recovery operations (see Figure 2). 


\section{Figure 2 Flow-Sheet For The Catalyst Recovery Scheme}

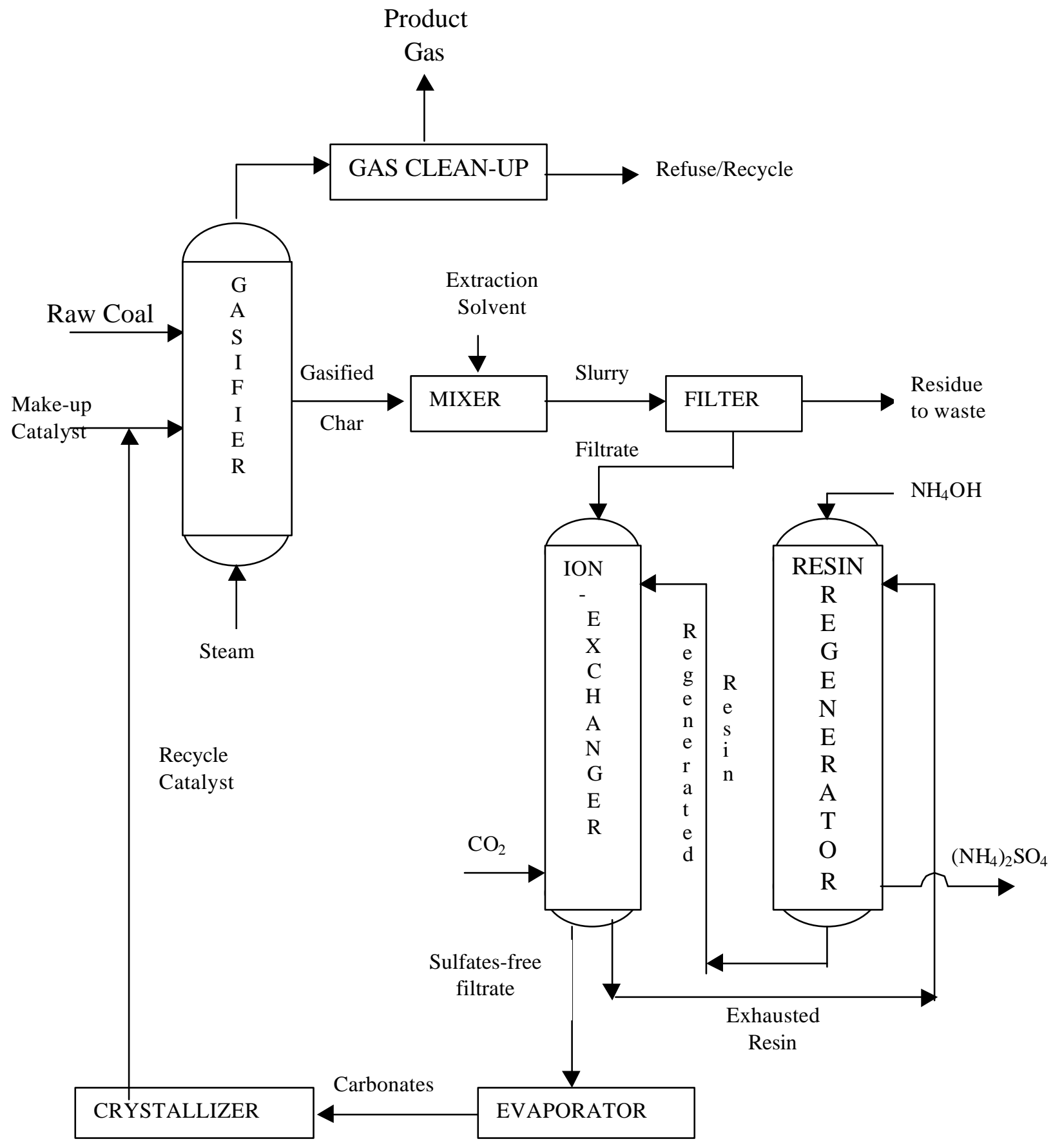




\subsection{Characterization Studies}

Scanning electron microscopy (SEM) studies of (i) coal + eutectic salt (pyrolyzed, but not yet gasified in the reactor), and (ii) gasified char samples (reactor-aged) have been conducted on several eutectic salt samples containing all three salts ( $\mathrm{Li}, \mathrm{Na}, \& \mathrm{~K}$ carbonates) as well as only two salts ( $\mathrm{Na} \& \mathrm{~K}$ carbonates).

Figures $3 \& 4$ (SEM4 and SEM5) show the SEM micrographs of a mixture of $10 \%$ Li-Na-K eutectic salt and $90 \%$ coal (pyrolyzed). Most of the particles (coal) appear amorphous, as expected since the x-ray diffraction studies showed a rather broad peak for carbon (graphite). Sharp peaks in the XRD were attributed to eutectic salts as well as individual constituents of the salt. The only sharp peaks attributed to coal were due to the presence of iron as an impurity in coal. Both Figures $3 \& 4$ were taken at a magnification of 500. Some coal particles are as large as 50-60 um, but most are smaller. One can also easily see a few crystalline particles (10-20 um) with sharp facets and corners. We attribute these to the eutectic salts.

Figures 5 \& 6 (SEM1 \& SEM2) show the electron micrographs of gasified char samples (reactor-aged) of the LNK-coal mixture. A dramatic change is obvious in the morphology and crystallinity of the sample and is consistent with the results obtained from the x-ray diffraction studies. XRD studies of reactor-aged samples showed a substantial increase in the sample crystallinity (due to the gasification of amorphous carbon). Here, we have mostly eutectic salt, presumably converted to sulfates as shown by XRD. Our plans include establishing the identity of the species present in these SEM micrographs by using energy dispersive analysis of $\mathrm{x}$-rays (EDAX). Our EDAX unit has been out of order for the past two months, and is expected to be fixed within the next month. Although, EDAX can not identify lithium, it will still be a very useful tool in establishing the identity of the reactor-aged species and the causes of catalyst deactivation. 
Figures 3 and 4 SEM micrographs of a mixture of $10 \%$ Li-Na-K eutectic salt, $90 \%$ coal (pyrolyzed)

SEM4

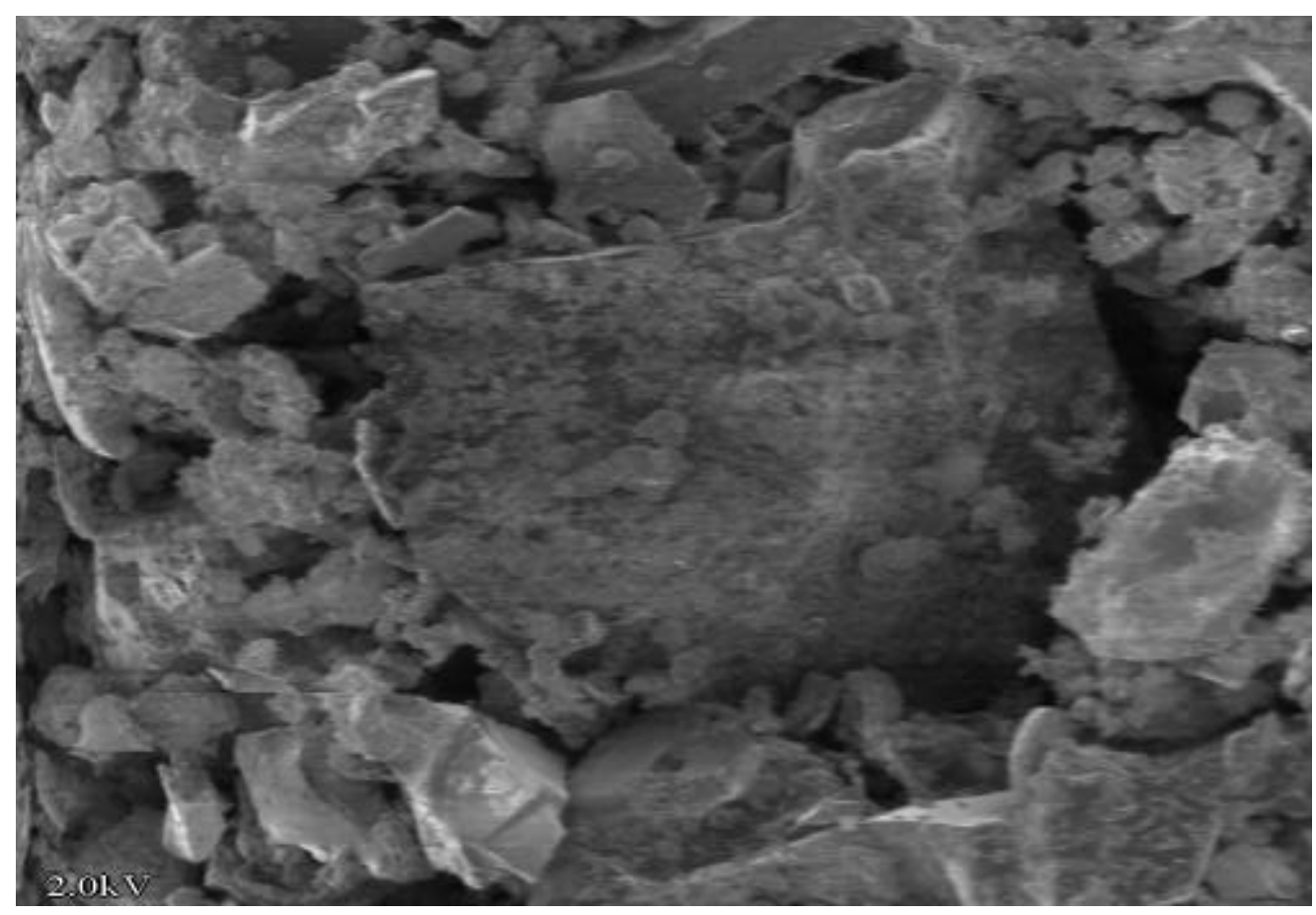

SEM5

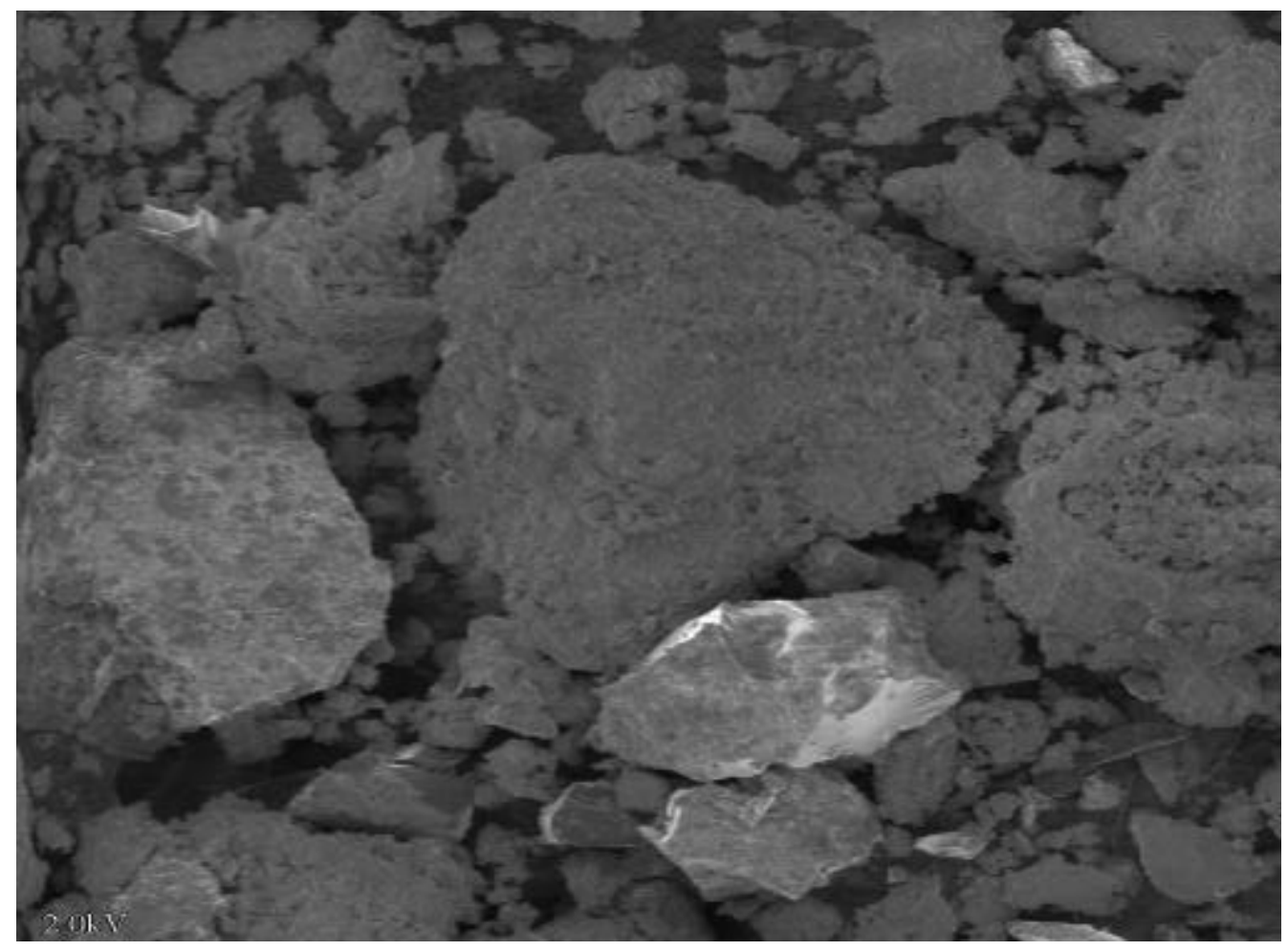


Figures 5 and 6 SEM micrographs of gasified char samples (reactor-aged) of the LNK-coal mixture

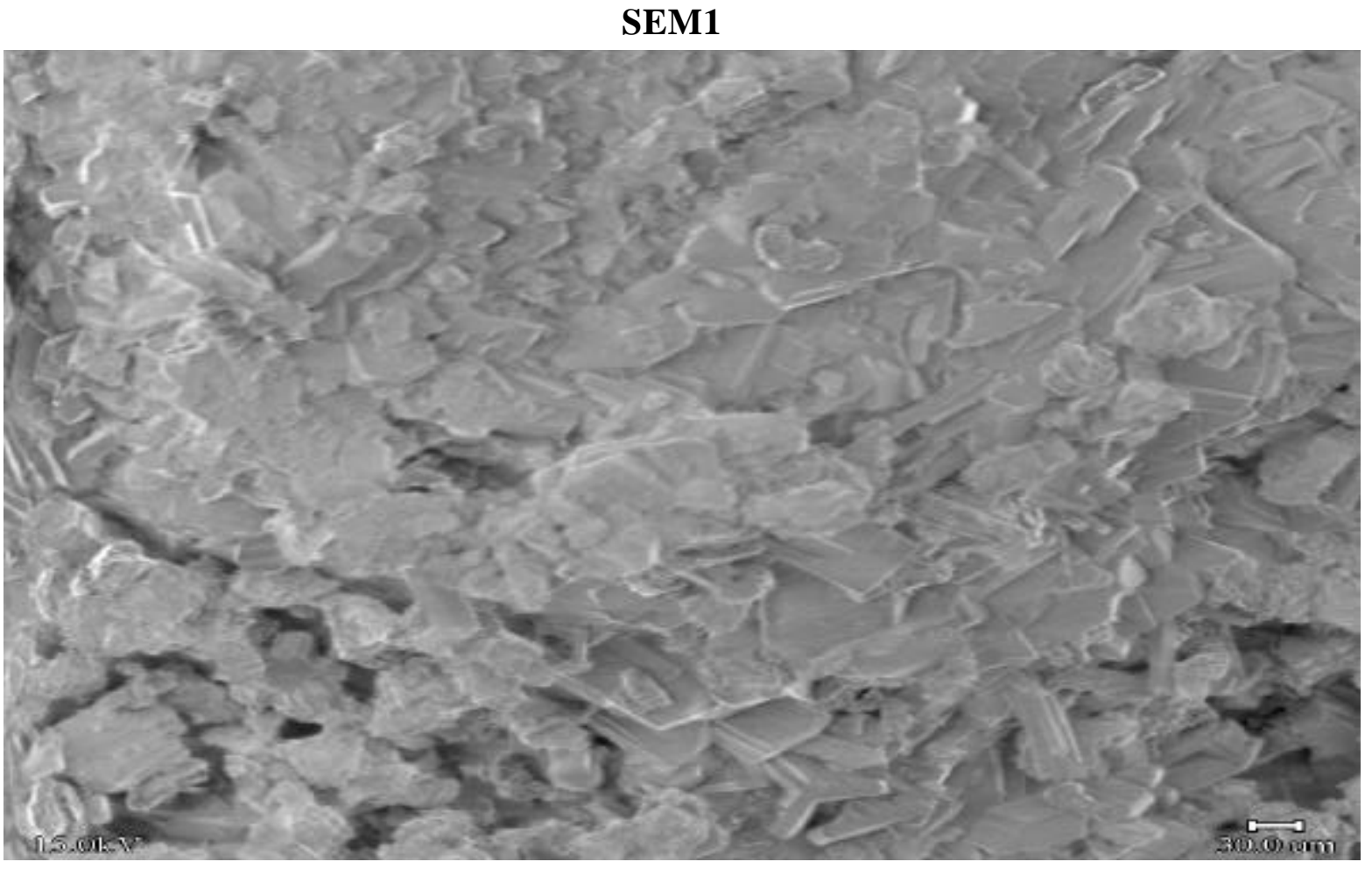

\section{SEM2}

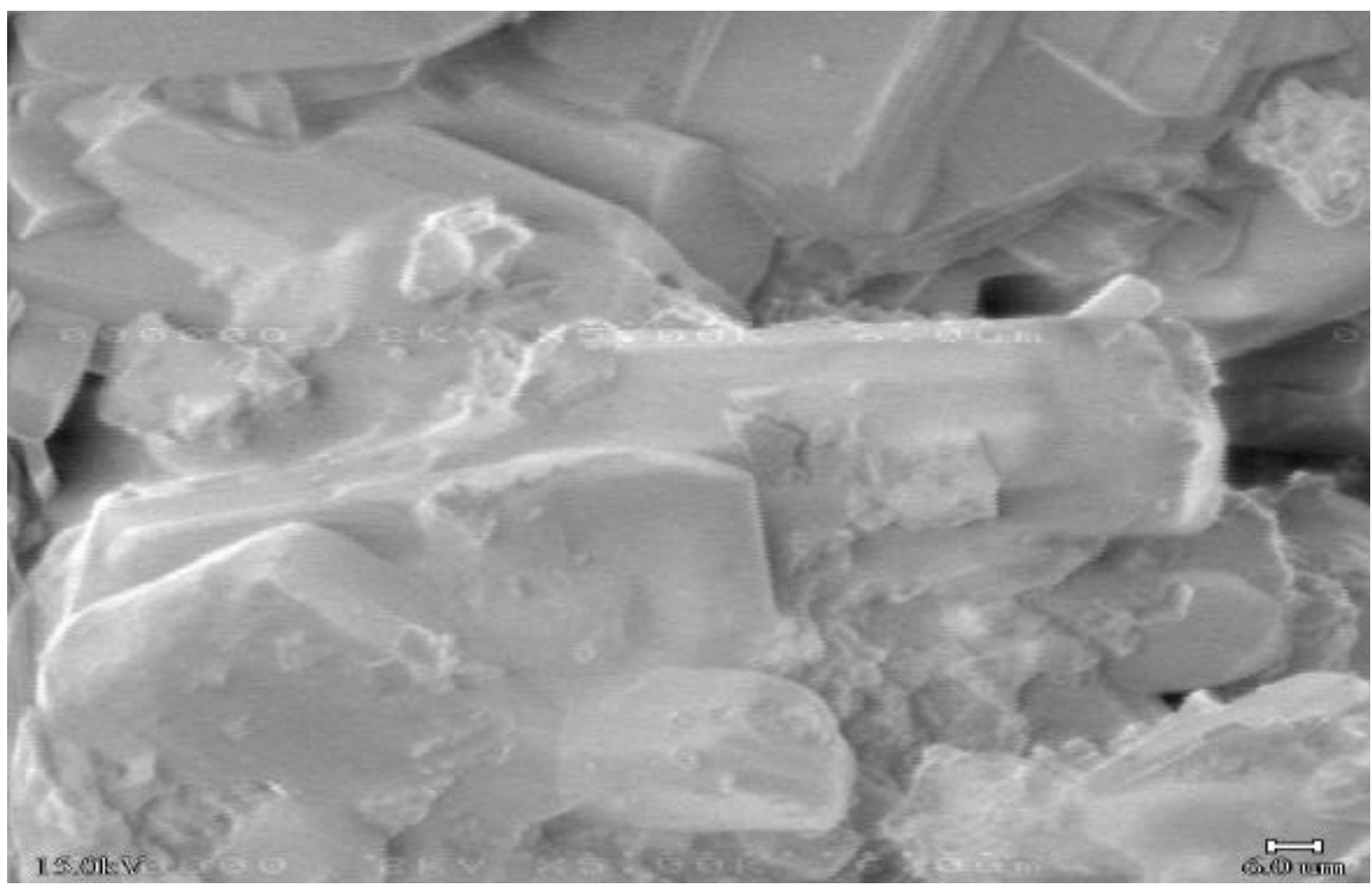




\subsection{Personnel Changes}

Mary Minton will be graduating in six weeks and will be replaced by Irais Passariello. Mary has just begun training Irais. Irais already has a B.S, degree in chemical engineering and will be able to spend more time (50\%) than an undergraduate student.

\subsection{CONCLUSIONS:}

- Acetic acid had more effect on the extraction of the ternary catalyst (LNK) ions than water.

- Based on the extraction results, the order of the recovery capability of $\mathrm{Na}_{2} \mathrm{CO}_{3}$ for acetic acid, sulfuric acid and water extractions is sulfuric acid $\geq$ acetic acid $>$ water; the order for $\mathrm{K}_{2} \mathrm{CO}_{3}$ is sulfuric acid > water >acetic acid; and the order for $\mathrm{Li}_{2} \mathrm{CO}_{3}$ is acetic acid $>$ sulfuric acid $>$ water.

- A flowsheet for the catalyst recovery process was proposed.

- Scanning electron microscopy (SEM) studies showed most of the particles (coal) appear amorphous. Some coal particles are as large as 50-60 um, but most are smaller. One can also easily see a few crystalline particles (10-20 um) with sharp facets and corners. The electron micrographs of gasified char samples (reactor-aged) of the LNK-coal mixture showed that a dramatic change is obvious in the morphology and crystallinity of the sample and is consistent with the results obtained from the X-ray diffraction studies. XRD studies of reactor-aged samples showed a substantial increase in the sample crystallinity (due to the gasification of amorphous carbon). The eutectic salt is presumably mostly converted to sulfates as shown by XRD. 


\section{$9 \quad$ Future Work:}

- Future work will focus on the economics of the catalyst recovery scheme outlined on the previous page.

- Our plans include establishing the identity of the species present in these SEM micrographs by using energy dispersive analysis of $\mathrm{x}$-rays (EDAX). It will be used to establish the identity of the reactor-aged species and the causes of catalyst deactivation.

- Completion of the data analysis and modeling and the submission of a final project report. 